\title{
Indices for the age of the creatine kinase M-chain in the blood
}

\author{
R.A. Wevers ${ }^{a}$, U. Hagelauer ${ }^{b}$, W. Stein ${ }^{\text {c }}$, J. Bohner $^{c}$, U. Faust ${ }^{b}$, \\ A.A.J. van Landeghem ${ }^{d}$ and J.B.J. Soons ${ }^{d}$ \\ ${ }^{a}$ Institute for Neurology, Department of Neurological Chemistry St. Radboud Hospital, Reinier Postlaan 4, \\ $6500 \mathrm{HB}$ Nijmegen (The Netherlands), ${ }^{b}$ Institut fur Biomedizinische Technik, University of Stuttgart, \\ Postfach 560, Azenbergstrasse 18, D-7000 Stuttgart I (FRG), ' Medizinische Klinik, ABT. Innere Medizin 4, \\ University of Tuebingen D-7400 Tuebingen (FRG) and d Department of Clinical Chemistry, St. Antonius \\ Hospital, State University Utrecht, Koekoekslaan 1, Nieuwegein (The Netherlands)
}

(Received June 13th, 1984; revision February 15th, 1985)

Key words: Apparent activation energy; $C K$ conversion factor; Modifying protein; Myocardial infarction; Multiple forms; Postsynthetic modification

\section{Summary}

The apparent activation energy of the CK reaction as well as the Michaelis-Menten constants and the isoelectric point of CK MM can be used as indices for the mean age of the CK M-chain in the blood in vivo and in vitro.

Modifications in the CK M-chain take place in vivo in the blood and in vitro in a serum matrix. Gradual increases in the apparent activation energy are also observed both in vivo and in vitro. It is confirmed that the modification in the CK M-chain causes a rise in the apparent activation energy, $u$.

A gradual increase in apparent activation energy, due to the ageing process of the CK M-chain, was observed after myocardial infarction. A significantly increased value for $u$ was observed at the time that total $\mathrm{CK}$ activity already had returned to reference values. In spite of the normal $C K$ value, the apparent activation energy still indicated that there had been myocardial damage.

The Michaelis-Menten constants for creatine phosphate and ADP are also influenced significantly by the modification in the M-chain. While the apparent activation cnergy increases, the Michaelis constants decrease in the order $\mathrm{MM}_{3}$, $\mathrm{MM}_{2}, \mathrm{MM}_{1}$. The Michaelis-Menten constants for both ADP and $\mathrm{CrP}$ can be used as an index for the mean age of the enzyme in the blood.

The Michaelis-Menten constants for $\mathrm{Cr} P$ and ADP show significant variations with the measuring temperature for virtually all CK MM forms. 


\section{Introduction}

Ageing effects of the MM and MB isozymes of creatine kinase (CK) have been described [1-6]. The ageing of the enzyme can be attributed to a modification in the $M$-chain caused by a serum protein $[1,2]$, for which the name CK conversion factor has been proposed [3]. As the same protein modifies the alpha chain of enolase as well [7], the name modifying protein was introduced by Wevers et al [7]. Recently, the modifying protein has been shown to have carboxypeptidase activity $[8,9]$. It separates the C-terminal lysine of the $\mathrm{CK}-\mathrm{M}$ chain from the rest of the chain. The future name for the modifying protein could well turn out to be carboxypeptidase $K$ as proposed by Edwards and Watts [8].

Both M-chains in the CK MM isozyme can be modified resulting in three $\mathrm{CK}$ MM multiple forms. This process of postsynthetic modification is quite slow for $\mathrm{CK}$ $\mathrm{MM}$. It starts as soon as the original form $\mathrm{CK} \mathrm{MM}_{3}$ reaches the circulation. It may take more than $48 \mathrm{~h}$ after a myocardial infarction before all $\mathrm{M}$-chains have been converted, resulting in the presence of the completely modified CK MM, form [1].

As shown by Hagelauer and Faust [6], the ageing of the enzyme is accompanied by variations of the apparert activation energy, $u$. Measurements during incubation of $\mathrm{CK} \mathrm{MM}$ in a serum matrix at $37^{\circ} \mathrm{C}$ during $72 \mathrm{~h}$ showed a gradual increase of the apparent activation energy [10]. A similar time is required to obtain complete in vitro modification of a comparable amount of $\mathrm{CK} \mathrm{MM}_{3}$ under the same conditions [2].

This paper combines the above-mentioned findings and tries to establish that the observed increase in apparent activation energy is caused by the modification in the CK M-chain. The in vivo changes in apparent activation energy are studied in the serum of patients after myocardial infarction. The influence of the modification on the Michaelis-Menten constant has also been studied. Practical consequences of the changes in the physicochemical parameters of the enzyme are discussed.

\section{Materials and methods}

\section{CK MM multiple forms}

A DEAE slurry was added to a human heart tissue extract. Conditions in this anion exchange step were chosen as described by Nealon and Henderson [11]. The three CK MM multiple forms were obtained by incubating the resulting extract with human serum $(25: 1 \mathrm{v} / \mathrm{v})$ for $90 \mathrm{~h}$ at $37^{\circ} \mathrm{C}$. Using agarose gel electrophoresis [1] the presence of all three CK MM forms was confirmed. Subsequently, an ethanol precipitation was carried out. Contaminating proteins were removed at an ethanol concentration of $50 \%(\mathrm{v} / \mathrm{v})$. The supernatant was made $70 \%(\mathrm{v} / \mathrm{v})$ in ethanol. The CK MM forms precipitate at this concentration. They were redissolved in a 10 $\mathrm{mmol} / \mathrm{l}$ Tris- $\mathrm{HCl}$ buffer, $\mathrm{pH}$ 7.4. The $\mathrm{CK} \mathrm{MM}$ forms were separated from each other by column isoelectric focusing as described before [12]. Only the top fractions of the three CK MM activity peaks were used. Ampholytes were removed on a Sephadex G-100 column $(1=26 \mathrm{~cm}, \varnothing=1 \mathrm{~cm}$; no. 17-0060-01, Pharmacia, Uppsala, Sweden). A $0.1 \mathrm{~mol} / \mathrm{I}$ Tris $-\mathrm{HCl}$ buffer, $\mathrm{pH} \mathrm{7.4,} \mathrm{was} \mathrm{used} \mathrm{for} \mathrm{elution.} \mathrm{The}$ 
pooled fractions with CK-activity were concentrated and subsequently transported on ice from The Netherlands to FRG by train. Upon arrival the enzymatic activity was almost the same as before the transport. The $\mathrm{CK}$ activities of the three preparations containing $\mathrm{CK} \mathrm{MM}_{1}, \mathrm{CK} \mathrm{MM}_{2}$ and $\mathrm{CK} \mathrm{MM}_{3}$ amounted to 13000 , 8200 and $10700 \mathrm{U} / 1$, respectively. The purity of the preparations was checked, using flat bed isoelectric focusing on agarose plates in accordance with the instructions of the manufacturer (Isogel agarose EF, no. 2206-111; ampholines, pH 5.0-8.0, no. 1818-126 LKB, Bromma, Sweden). The contamination of each MM form with other MM forms was estimated to be <5\%. CK enzymatic determinations were performed with the reverse reaction using NAC activated reagents (nos. 14109-14111, E. Merck, Darmstadt, FRG) according to the recommendations of the German, Dutch and Scandinavian societies of clinical chemistry.

\section{Apparent activation energy}

Determinations of apparent activation energy, $u$, were performed for the multiple CK MM forms on 1:30 dilutions of the original preparations in a $100 \mathrm{mmol} / \mathrm{l}$ imidazole buffer, $\mathrm{pH} 6.7$ (no. 14109, Merck) and in a serum matrix adjusted to $\mathrm{pH}$ 7.4 with $1 \mathrm{~mol} \mathrm{HCl} / 1$. Reagents corresponding to the recommended method (Creatine kinase test system, nos. 14109-14111, Merck) were used to determine the catalytic activity at two temperatures in one assay. A preincubation time of $5 \mathrm{~min}$ was used to allow for complete reactivation. Values for $u$ were calculated according to the equation below. The standard temperature interval for determination of the apparent activation energy was $298 / 308 \mathrm{~K}\left(25 / 35^{\circ} \mathrm{C}\right)$. Values for the apparent activation energy given below are defined for this temperature interval. It is related to the internationally used assay temperatures for CK determinations and represents a practical compromise between a sufficiently high absorbance change and the stability of the enzyme. Further details such as turnover limitation are described elsewhere [6,10]. Technical information can be obtained from Dr. Hagelauer, Institut für Biomedizinische Technik, University of Stuttgart, D-7000 Stuttgart-1, FRG.

Additionally, the temperature interval was varied in $2 \mathrm{~K}$ steps to demonstrate Arrhenius plots in the interval 298/310 K. The apparent activation energy can be defined as [13]:

$u=R T_{1} T_{2} \cdot \frac{\ln \left(v_{2} / v_{1}\right)}{\left(T_{2}-T_{1}\right)}$,

where $v_{1}$ and $v_{2}$ are the substrate turnover rates measured at the temperatures $T_{1}$ and $T_{2}$ and $R$ is the universal gas constant.

\section{Michaelis-Menten constants}

A random $\mathrm{Bi} \mathrm{Bi}$ reaction mechanism is generally accepted for the $\mathrm{CK}$ reaction. For this type of reaction four dissociation constants $K_{\mathrm{a}}, K_{\mathrm{b}}, K_{\mathrm{ia}}$ and $K_{\mathrm{ib}}$ can be discerned for the reactions $\mathrm{EB}+\mathrm{A} \leftrightarrow \mathrm{EAB}, \mathrm{EA}+\mathrm{B} \leftrightarrow \mathrm{EAB}, \mathrm{E}+\mathrm{A} \leftrightarrow \mathrm{EA}$ and $\mathrm{E}+$ $\mathrm{B} \leftrightarrow \mathrm{EB}$, respectively [14]. $K_{\mathrm{a}}$ and $K_{\mathrm{b}}$ are the respective Michaelis-Menten constants for substrates A (ADP) and B (creatine phosphate, CrP). The four constants 
have been determined for the CK MM multiple forms in this two substrate system using primary and secondary plots according to refs. [14-17]. It was possible to calculate standard enthalpy changes (Delta Hs) by means of the Van 't Hoff equation.

Enzyme activity was monitored continuously using $\mathrm{CrP}\left(\mathrm{CrP} \cdot \mathrm{Na}_{2} \cdot 4 \mathrm{H}_{2} \mathrm{O}\right.$, Boehringer, no. 621714) and ADP (free acid, Boehringer, no. 102164) and reagents from E. Merck (we thank Dr. Vormbruck for supplying us with these special, ADP-free reagent kits). Absorbance was measured at $334 \mathrm{~nm}$ with a photometer (Eppendorf M1101 with recorder) at 25,30 and $37^{\circ} \mathrm{C}$. At these temperatures the $\mathrm{pH}$ of the reaction mixtures was $6.5,6.6,6.7$ paralleling the $\mathrm{pH}$ optimum of $\mathrm{CK}$ [18]. The samples were stored at $4^{\circ} \mathrm{C}$ and diluted with imidazole buffer prior to the assay to give activities of $<800 \mathrm{U} / 1$. Lag phases appeared to vary between $<2 \mathrm{~min}$ $\left(\mathrm{MM}_{1}, 25^{\circ} \mathrm{C}\right)$ to about $8 \mathrm{~min}\left(\mathrm{MM}_{3}, 37^{\circ} \mathrm{C}\right.$, low substrates $)$. Afterwards the reaction rate was linear for at least $5 \mathrm{~min}$. Apart from the substrates, the final concentrations of all reactants corresponded to the internationally recommended, imidazole buffered, NAC reactivated method [18]. For this purpose and for the sake of practicability total (T) concentrations are given for ADP (T-ADP) and CrP (T-CrP), especially as the influence of imidazole, EDTA, AMP, etc. on the concentration of the respective substrates is unknown. Estimations of the concentrations of $\mathrm{Mg}-\mathrm{ADP}$, free $\mathrm{CrP}$ ( $\mathrm{F}-\mathrm{CrP}$ ) and $\mathrm{ADP}^{3-}$ in this complex reaction mixture were calculated using the procedure of Morrison [19]. The concentration of $\mathrm{ADP}^{3-}$, which may be an inhibitor, was below $0.02 \mathrm{mmol} / 1$ in every case. At the recommended concentrations for T-ADP ( $2 \mathrm{mmol} / \mathrm{l})$ and T-CrP $(30 \mathrm{mmol} / 1)$ the concentrations of MgADP in the assay are $1.56\left(37^{\circ} \mathrm{C}\right), 1.61\left(30^{\circ} \mathrm{C}\right)$ and $1.64 \mathrm{mmol} / 1\left(25^{\circ} \mathrm{C}\right)[19]$, whereas $\mathrm{F}-\mathrm{Cr} P$ shows a concentration of $25.8 \mathrm{mmol} / 1$. Under the conditions chosen in our experiments the following results are obtained:

$\mathrm{MgADP}=0.869 \cdot \mathrm{T}-\mathrm{ADP}($ at $\mathrm{pH} 6.5$ and $\mathrm{T}-\mathrm{CrP}=6 \mathrm{mmol} / 1)$

and

$\mathrm{MgADP}=0.913 \cdot \mathrm{T}-\mathrm{ADP}($ at $\mathrm{pH} 6.7$ and $\mathrm{T}-\mathrm{CrP}=0.5 \mathrm{mmol} / \mathrm{l})$

To cover the whole range of $\mathrm{pH}$ and concentrations used by only one equation and an error of $<3 \%$, we calculated:

$\mathrm{Mg}-\mathrm{ADP}=0.89 \cdot \mathrm{T}-\mathrm{ADP}($ for $0.5<\mathrm{T}-\mathrm{CrP}<6$ and $6.5<\mathrm{pH}<6.7)$.

Similarly, free creatine phosphate is given by:

$\mathrm{F}-\mathrm{CrP}=0.75 \cdot \mathrm{T}-\mathrm{CrP}$.

\section{Initial velocity}

The initial velocity $v$ for a rapid equilibrium random $\mathrm{Bi} B \mathrm{Bi}$ two substrate system is 
described by $[14,20]$ :

$\frac{1}{v}=\frac{1}{V_{\mathrm{r}}}+\frac{K_{\mathrm{a}}}{V_{\mathrm{r}}(\mathrm{A})}+\frac{K_{\mathrm{b}}}{V_{\mathrm{r}}(\mathrm{B})}+\frac{K_{\mathrm{ia}} K_{\mathrm{b}}}{V_{\mathrm{r}}(\mathrm{A})(\mathrm{B})}$,

where $V_{\mathrm{r}}$ is the maximum velocity for the reverse reaction catalysed by $\mathrm{CK}$ and where (A) and (B) are the concentrations of $\mathrm{Mg}-\mathrm{ADP}$ and $\mathrm{F}-\mathrm{CrP}$ as given above.

\section{Results}

\section{Arrhenius plots and apparent activation energy}

The influence of temperature on the turnover rates for the three multiple forms is shown in Fig. 1. The slope decreases in the order $\mathrm{MM}_{1}, \mathrm{MM}_{2}, \mathrm{MM}_{3}$, corresponding to a decrease in apparent activation energy. A straight line is observed for $\mathbf{M M}_{1}$, whereas a deviation from linearity occurs for $\mathrm{MM}_{2}$ and more pronounced for $\mathrm{MM}_{3}$. Thus, the apparent activation energy depends on the temperature interval chosen for its determination. Compared to the smallest interval $298 / 300 \mathrm{~K}\left(25 / 27^{\circ} \mathrm{C}\right)$, the value, $u$, for $\mathrm{MM}_{2}$ and $\mathrm{MM}_{3}$ decreases by 10 and $20 \%$, respectively, when extending the temperature interval to $298 / 310 \mathrm{~K}\left(25 / 37^{\circ} \mathrm{C}\right)$. The apparent activation energy, $u$, was measured in a buffer and a serum matrix (Table I). Significantly differing values were found for the three CK MM multiple forms in the serum matrix, ranging from $49.1-66.8 \mathrm{~kJ} / \mathrm{mol}$. The values of $u$ in buffer are not significantly higher than in the serum matrix. The values found for $\mathrm{MM}_{2}$ are almost the arithmetic mean value as expected on the basis of the proposed chain composition of the three MM forms [1].

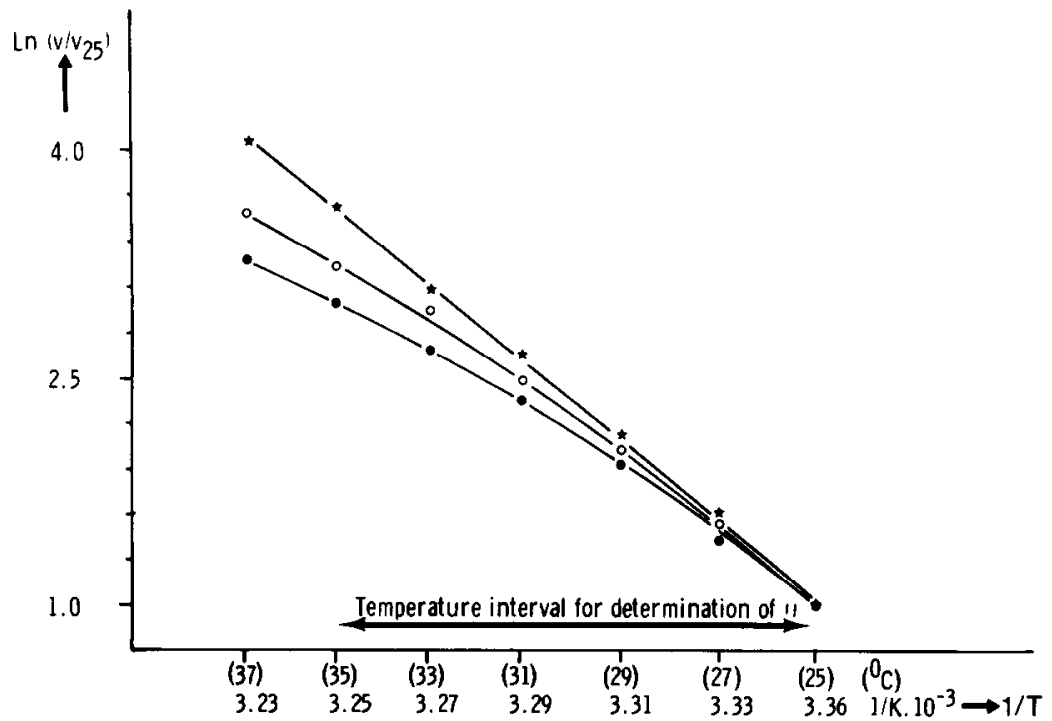

Fig. 1. Arrhenius plot for the three CK MM forms. $\star$ CK $\mathrm{MM}_{1} ; \mathrm{O}, \mathrm{CK} \mathrm{MM}_{2} ; \bullet, C K \mathrm{MM}_{3}$. 
TABLF. I

Apparent activation energy $u$ for the multiple forms of CK MM in imidazole buffer and in a serum matrix "

\begin{tabular}{|c|c|c|c|c|c|c|}
\hline \multirow{2}{*}{$\begin{array}{l}\text { Activation } \\
\text { energy }\end{array}$} & \multicolumn{2}{|l|}{$\mathrm{MM}_{1}$} & \multicolumn{2}{|l|}{$\mathrm{MM}_{2}$} & \multicolumn{2}{|l|}{$\mathrm{MM}_{3}$} \\
\hline & Serum & Buffer & Serum & Buffer & Serum & Buffer \\
\hline$\overline{u(\mathrm{~kJ} / \mathrm{mol})}$ & 66.8 & 67.5 & 59.2 & 60.3 & 49.1 & 49.8 \\
\hline
\end{tabular}

a Measurements of $u$ are the mean of three experiments ( $\mathrm{CV}<2 \%$ in all cases).

In vivo changes in apparent activation energy

In healthy individuals, the value of $u$ never exceeded $55 \mathrm{~kJ} / \mathrm{mol}$. The apparent activation energy in 360 sera from 62 cardiac care patients with suspected and confirmed myocardial infarction, however, ranged between 49 and $68 \mathrm{~kJ} / \mathrm{mol}$.

Serial determinations of $u$ in subsequent serum samples from 8 patients with acute myocardial infarction showed a continuous increase from $51 \mathrm{~kJ} / \mathrm{mol} \mathrm{im-}$ mediately after the infarction to $68 \mathrm{~kJ} / \mathrm{mol}$ three days later. Even when the total CK activity had already returned to values within the reference range, the apparent activation energy was still evidently increased. Figure 2 shows the apparent activation energy values in the serum of these 8 patients taken at various times after the infarction. A gradual increase in apparent activation energy is observed depending on the time interval between the infarction and the blood sampling. The apparent activation energy reaches the maximal value of $68 \mathrm{~kJ} / \mathrm{mol}$ about three days after the myocardial infarction. The in vivo shift in the circulating CK MM multiple forms is completed in the same time interval.

\section{In vitro changes in apparent activation energy}

Figure $3 \mathrm{a}$ shows that the apparent activation energy for the partially purified $\mathrm{CK}$ $\mathrm{MM}$ multiple forms increases upon incubation at $37^{\circ} \mathrm{C}$ in a $\mathrm{pH}$ controlled serum

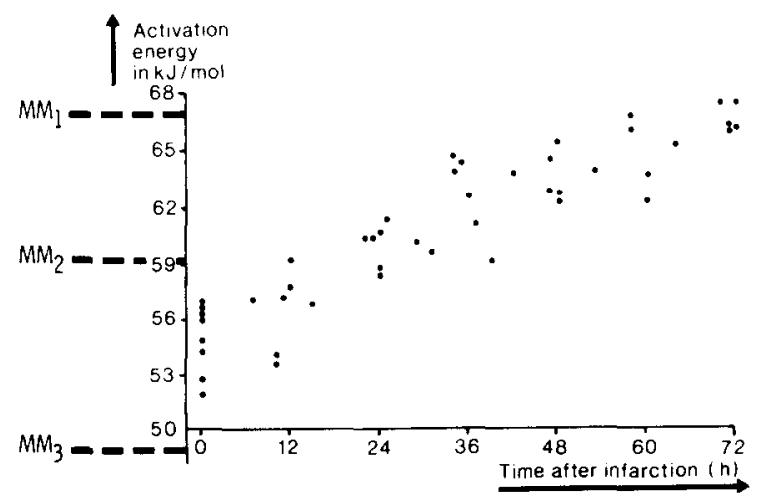

Fig. 2. Increase in apparent activation energy in serum after myocardial infarction. Values are given for subsequent serum samples $(n=44)$ from eight patients with confirmed myocardial infarction. 

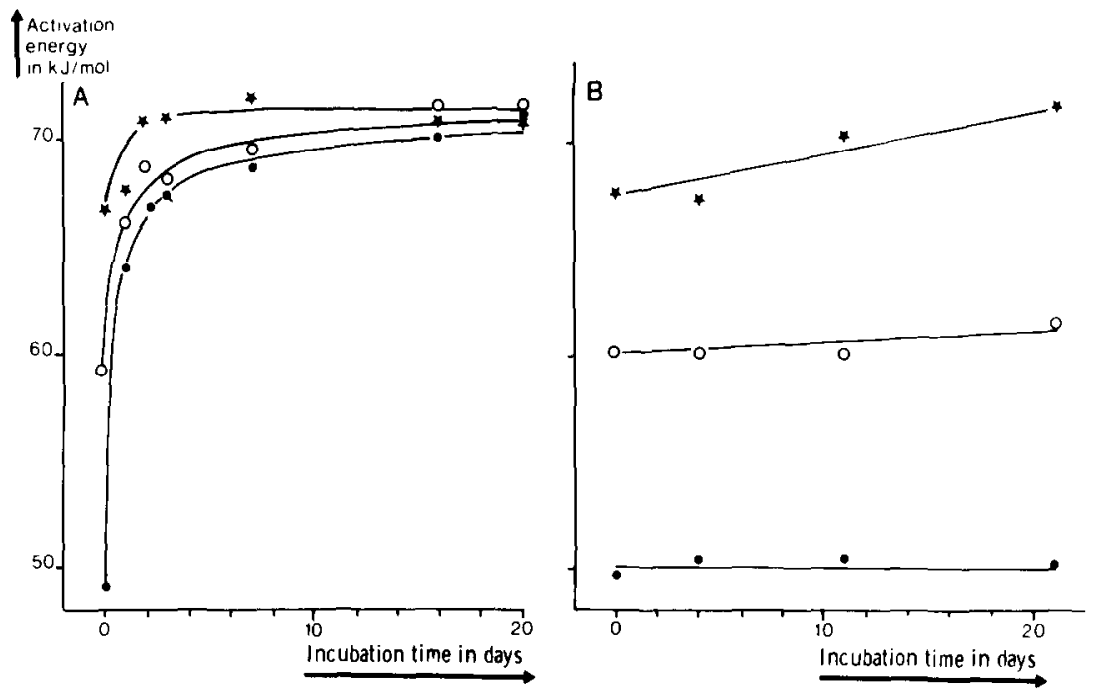

Fig. 3. Changes in apparent activation energy during in vitro incubation of CK MM multiple forms: $\star$, $\mathrm{CK} \mathrm{MM}_{1} ; \mathrm{O}, \mathrm{CK} \mathrm{MM}_{2} ; \bullet, \mathrm{CK} \mathrm{MM}_{3}$. A. Serum matrix. B. Imidazole buffer matrix.

matrix ( $\mathrm{pH}$ 7.4). The three preparations show a characteristic rapid increase of $u$ during the first three days indicating the turnover of $\mathrm{CK} \mathrm{MM}_{3}$ into $\mathrm{CK} \mathrm{MM}_{2}$ and later on into $\mathrm{CK} M M_{1}$. After about 20 days, all fractions reach the same maximum of $71 \mathrm{~kJ} / \mathrm{mol}$, which is $3 \mathrm{~kJ} / \mathrm{mol}$ higher than for purified $\mathrm{CK} \mathrm{MM}_{1}$. The time course resembles a first order reaction as expected for the proposed turnover model.
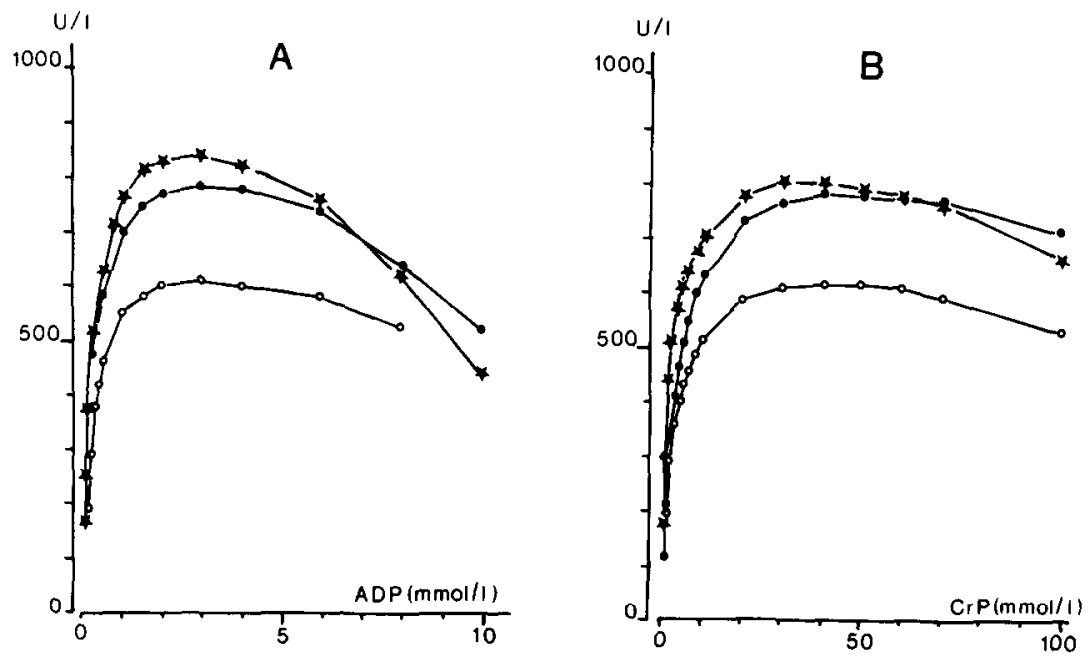

Fig. 4. Dependence of $\mathrm{CK}$ activity at $30^{\circ} \mathrm{C}$ on the substrate concentration for $\star, C K M_{1} ; O, C K$ $\mathrm{MM}_{2} ; \bullet, \mathrm{CK} \mathrm{MM}_{3}$. A. Varying concentrations of ADP (T-CrP, $30 \mathrm{mmol} / \mathrm{l}$ ). B. Varying concentrations of $\mathrm{CrP}$ (T-ADP: $2 \mathrm{mmol} / \mathrm{l}$ ). 


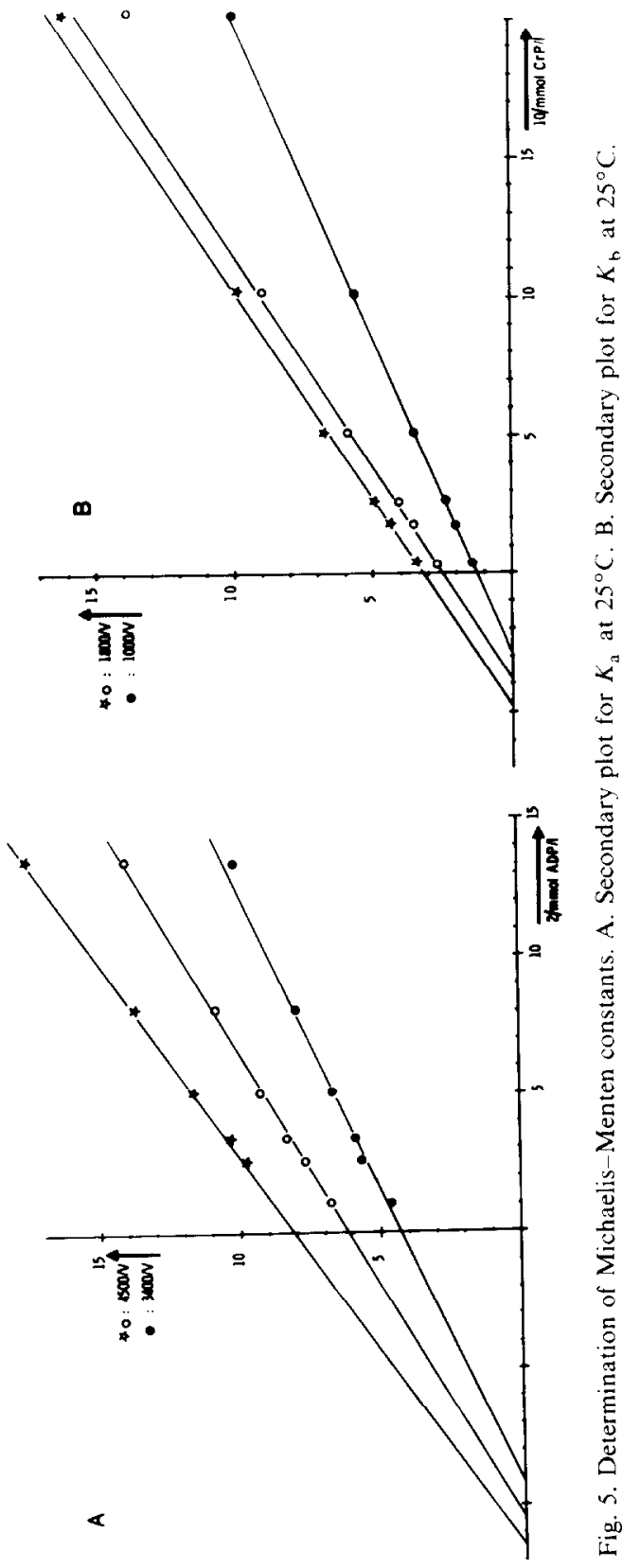


In a buffer matrix, however, only a slight rise in $u$ is observed for CK $\mathrm{MM}_{1}$ and $\mathrm{CK} \mathrm{MM}_{2}$ and no significant change occurred for CK $\mathrm{MM}_{3}$. These results are not biased by the inactivation process of the enzyme. The decrease in catalytic activity was essentially the same for the three forms during the entire incubation period.

\section{Michaelis-Menten constants}

Figure 4a gives the results of varying ADP concentrations on the reaction velocity at a fixed $\mathrm{CrP}$ concentration of $30 \mathrm{mmol} / \mathrm{l}$, while in Fig. 4b the CRP concentration was changed using a fixed $\mathrm{CrP}$ concentration of $2 \mathrm{mmol} / \mathrm{l}$. There appears to be an obvious optimum in reaction velocity for all CK MM multiple forms at $30 \mathrm{mmol}$ $\mathrm{CrP} / 1$ and $3 \mathrm{mmol} \mathrm{ADP} / 1$, respectively. Higher substrate concentrations inhibit the enzymatic activity.

For the determination of the kinetic parameters primary plots were made in which the reciprocal initial velocity data were plotted against the reciprocal concentration of substrate A at various fixed concentrations of substrate B. Analogously reciprocal initial velocities were plotted versus $1 / \mathrm{B}$ at various fixed concentrations of substrate $A$. In every case these double reciprocal primary plots converged above the abscissa, which is in agreement with a random $\mathrm{Bi} B i$ mechanism. Figures $5 \mathrm{a}$ and $5 \mathrm{~b}$ represent secondary plots for the determination of $K_{\mathrm{a}}$ and $K_{\mathrm{b}}$ in which the intercepts of the primary plots have been replotted versus $1 / \mathrm{A}$ and $1 / \mathrm{B}$, respectively. Similarly $K_{\mathrm{ia}}$ and $K_{\mathrm{ib}}$ were determined by secondary plots in which the slopes of the primary plots have been replotted versus $1 / \mathrm{A}$ and $1 / \mathrm{B}$, respectively (not shown). The Michaelis constants $K_{\mathrm{a}}$ and $K_{\mathrm{b}}$ for the three multiple forms of CK MM are given in Table II. Highest values for both substrates are found for CK $\mathrm{MM}_{3}$, the CK MM form present in muscular tissue. Values for $K_{\mathrm{ia}}$ and $K_{\mathrm{ih}}$ are presented in Table III. The dependence of the constants $K_{\mathrm{a}}, K_{\mathrm{b}}, K_{\mathrm{ia}}$ and $K_{\mathrm{ib}}$ on temperature is obvious in the Tables II and III. From these data, the apparent standard enthalpy change during the reaction of the enzyme with its substrate (Delta

\section{TABLE II}

Michaelis-Menten constants (1 SD) in mmol/ $\mathrm{f}$ for T-ADP $\left(K_{\mathrm{a}}\right)$ and for $\mathrm{T}-\mathrm{CrP}\left(K_{\mathrm{b}}\right)$ and the influence of temperature on these parameters ${ }^{a}$

\begin{tabular}{|c|c|c|c|c|c|c|}
\hline \multirow{2}{*}{$\begin{array}{l}\text { Temperature } \\
\left({ }^{n} \mathrm{C}\right)\end{array}$} & \multicolumn{3}{|l|}{$\mathbf{K}_{\mathrm{a}}$} & \multirow{2}{*}{$\begin{array}{l}\mathbf{K}_{\mathrm{b}} \\
\mathrm{MM}_{1}\end{array}$} & \multirow[b]{2}{*}{$\mathrm{MM}_{2}$} & \multirow[b]{2}{*}{$\mathrm{MM}_{3}$} \\
\hline & $\mathrm{MM}_{1}$ & $\mathrm{MM}_{2}$ & $\mathrm{MM}_{3}$ & & & \\
\hline 25 & $\begin{array}{c}0.17 \\
(0.003)\end{array}$ & $\begin{array}{l}0.19 \\
(0.007)\end{array}$ & $\begin{array}{c}0.22 \\
(0.02)\end{array}$ & $\begin{array}{c}2.09 \\
(0.11)\end{array}$ & $\begin{array}{c}2.65 \\
(0.12)\end{array}$ & $\begin{array}{c}3.28 \\
(0.05)\end{array}$ \\
\hline 30 & $\begin{array}{c}0.21 \\
(0.008)\end{array}$ & $\begin{array}{c}0.24 \\
(0.01)\end{array}$ & $\begin{array}{c}0.28 \\
(0.03)\end{array}$ & $\begin{array}{c}2.13 \\
(0.08)\end{array}$ & $\begin{array}{c}2.87 \\
(0.14)\end{array}$ & $\begin{array}{c}3.47 \\
(0.12)\end{array}$ \\
\hline 37 & $\begin{array}{c}0.26 \\
(0.02)\end{array}$ & $\begin{array}{c}0.34 \\
(0.01)\end{array}$ & $\begin{array}{c}0.39 \\
(0.06)\end{array}$ & $\begin{array}{c}2.66 \\
(0.06)\end{array}$ & $\begin{array}{c}3.28 \\
(0.15)\end{array}$ & $\begin{array}{c}4.27 \\
(0.18)\end{array}$ \\
\hline $\begin{array}{l}\text { Delta Hs } \\
r\end{array}$ & $\begin{array}{l}26 \\
0.99\end{array}$ & $\begin{array}{l}37 \\
0.99\end{array}$ & $\begin{array}{l}36 \\
0.99\end{array}$ & $\begin{array}{l}16 \\
0.93\end{array}$ & 14 & 17 \\
\hline
\end{tabular}

${ }^{a}$ Furthermore, the table shows the Delta Hs values in $\mathrm{kJ} / \mathrm{mol} ; r$, corr coeff in linear regression for $\ln (K)$ versus $1 / T$. 
TABLE III

The dissociation constants $K_{\mathrm{ia}}$ and $K_{\mathrm{ib}}$ and the influence of temperature on these parameters "

\begin{tabular}{|c|c|c|c|c|c|c|}
\hline \multirow{2}{*}{$\begin{array}{l}\text { Temperature } \\
\left({ }^{\circ} \mathrm{C}\right)\end{array}$} & \multicolumn{3}{|l|}{$K_{\text {ia }}$} & \multicolumn{3}{|l|}{$K_{\text {in }}$} \\
\hline & $\mathrm{MM}_{1}$ & $\mathrm{MM}_{2}$ & $\mathrm{MM}_{3}$ & $\mathrm{MM}_{1}$ & $\mathrm{MM}_{2}$ & $\mathrm{MM}_{3}$ \\
\hline 25 & 0.25 & 0.25 & 0.27 & 3.06 & $3 . \overline{53}$ & 4.09 \\
\hline 30 & 0.38 & 0.35 & 0.37 & 3.51 & 3.92 & 4.40 \\
\hline 37 & 0.42 & 0.53 & 0.52 & 4,19 & 5.11 & 5.74 \\
\hline Delta Hs & 33 & 48 & 42 & 28 & 25 & 22 \\
\hline$r$ & 0.90 & 0.98 & 0.99 & 0.99 & 0.93 & 0.97 \\
\hline
\end{tabular}

${ }^{a}$ Furthermore the table shows the Delta Hs values in $\mathrm{kJ} / \mathrm{mol} ; r$, corr coeff in linear regression for $\ln (K)$ versus $1 / T$.

TABLE IV

Initial velocities $v$ given as percentages of the maximum reverse velocities $V_{\mathrm{r}}$ at various temperatures

\begin{tabular}{llll}
\hline $\begin{array}{l}\text { Temperature } \\
\left({ }^{\circ} \mathrm{C}\right)\end{array}$ & $\mathrm{MM}_{1}$ & $\mathrm{MM}_{2}$ & $\mathrm{MM}_{3}$ \\
\hline 25 & $83.3 \%$ & $81.0 \%$ & $78.0 \%$ \\
30 & 81.0 & 78.1 & 74.3 \\
37 & 76.9 & 72.1 & 68.1 \\
\hline
\end{tabular}

Hs) can be calculated (Tables II and III). The highest value is found for the reaction $F+A \leftrightarrow F . A$ and the lowest value for the reaction $E A+B \leftrightarrow E A B$. No significant differences in the standard enthalpy change were found among the three MM forms.

\section{Initial velocity}

Table IV gives the calculated initial velocities at various temperatures. At $25^{\circ} \mathrm{C}$, the initial velocity of $\mathrm{CK} \mathrm{MM}_{1}$ is $83.3 \%$ of the maximal velocity $\left(V_{r}\right)$ and $78 \%$ for the $\mathrm{CK} \mathrm{MM}$ form. When measuring at $37^{\circ} \mathrm{C}$, the values for the initial velocity for the three CK MM forms are distinctly lower than at $25^{\circ} \mathrm{C}$.

\section{Discussion}

The increase in a serum matrix in the value for the apparent activation energy of the CK reaction has been described as an ageing effect of CK MM [10]. The changes in the electrophoretic CK MM pattern that are due to an alteration in the isoelectric point of the enzyme have also been considered as an ageing effect [1-3]. The changes in the CK MM sub-handing pattern closely parallel the observed changes in apparent activation energy. About $90 \%$ of the total change in apparent activation energy takes place within the first three days, when incubating $\mathrm{CK} \mathrm{MM}_{3}$ in a serum matrix at $37^{\circ} \mathrm{C}$. The modifications in the $\mathrm{CK}$ M-chain follow the same time course $[1,2]$. Furthermore, it was observed that the changes in apparent activation energy 
and in electrophoretic pattern only take place in a serum matrix and not in a buffer system. This investigation was carried out to find out whether the changes in the CK MM electrophoretic pattern and in the apparent activation energy can be explained by the same mechanism.

The measurements on partially purified CK MM multiple forms have shown significant differences in the apparent activation energy, $u$, between the three CK MM forms. The lowest apparent activation energy was measured in case of the partially purified native form CK $\mathrm{MM}_{3}$. The observed value of $49.8 \mathrm{~kJ} / \mathrm{mol}$ is in good agreement with data for CK MM from muscular tissue [10]. Upon modification of the first M-chain $\left(\mathrm{MM}_{2}\right)$ a value of $60.3 \mathrm{~kJ} / \mathrm{mol}$ is found which becomes even higher $(67.5 \mathrm{~kJ} / \mathrm{mol})$ after modification of the second $\mathrm{M}$-subunit $\left(\mathrm{MM}_{1}\right)$. These changes in the $\mathrm{CK}$ molecule also appear to take place in vivo. The $u$ value in healthy individuals ranges between 49 and $55 \mathrm{~kJ} / \mathrm{mol}$. Apparently, the native form CK $\mathrm{MM}_{3}$ is often accompanied in the blood by relatively small amounts of the other MM forms. Circulating CK MM is almost always a mixture of native $\mathrm{CK} \mathrm{MM}_{3}$ and the two modified forms CK $\mathrm{MM}_{2}$ and CK $\mathrm{MM}_{1}$. The values for the apparent activation energy found in 360 sera of 62 patients with possible or definite myocardial infarction ranged between 49 and $68 \mathrm{~kJ} / \mathrm{mol}$. This can be explained satisfactorily by assuming different compositions of CK MM multiple forms in these serum samples. The influence of CK MB on the value of $u$ is negligible due to the small catalytic activity compared to CK MM.

Measuring the apparent activation energy, $u$, in serial serum samples of eight patients with confirmed myocardial infarction gave a continuous increase in apparent activation energy. Values found ranged from $51 \mathrm{~kJ} / \mathrm{mol}$ immediately after the infarction rising later to $68 \mathrm{~kJ} / \mathrm{mol}$. As Table I shows, this may conclusively be explained by the initial release of $\mathrm{CK} \mathrm{MM}_{3}$ into the circulation and the subsequent turnover into $\mathrm{MM}_{2}$ and $\mathbf{M M}_{1}$. This is also in agreement with Fig. 3 and with our recently published data on the gradual changes in apparent activation energy of CK in the human blood circulation [21]. In addition, individual $u$ values for CK isozymes [10], $C K$ variants [22] and some other isoenzyme systems [23,24] have already been described. It is important to note that after myocardial infarction the apparent activation energy remains at an increased level whereas the CK activity already returns to normal in $72 \mathrm{~h}$ (Fig. 2). Theoretically, this would allow the determination of muscular damage even after the normalisation of the serum CK level of the patient. A sudden decrease in the apparent activation energy may be caused by the release of new enzyme from muscular tissue. Reinfarction can be demonstrated biochemically in this way.

The influence of the modification in the $\mathrm{CK} \mathrm{M}$-chain is not restricted to the alteration in the $u$ value. It has already been described that the isoelectric point changes as well [12]. We have found a third property of the enzyme that appears to be changed upon modification of the M-chain. As the modification goes on, the Michaelis-Menten constants for ADP and for $\mathrm{CrP}$ decrease. The highest values are found for the $\mathrm{MM}_{3}$ form, the form of the enzyme occurring in muscular tissue. The lowest values are found for CK $\mathrm{MM}_{1}$. The constants of the individual MM forms may be arranged in a characteristic sequence $K_{\mathrm{a}}<K_{\mathrm{ia}}<K_{\mathrm{b}}<K_{\mathrm{ib}}$. Changes in the 
Michaelis-Menten constants of an enzyme during its presence in the blood circulation have been described for other enzyme systems [25].

Our experiments prove that the phenomena described are caused by the same alteration within the CK M-chain. During its stay in the circulation the M-chain undergoes a postsynthetic modification brought about by a human serum protein for which the name 'modifying protein' has been proposed [7]. This explains why the modification cannot be demonstrated in buffer matrices that do not contain the modifying protein. The modification in the M-chain causes obvious changes in the Michaelis-Menten constants, the apparent activation energy and the isoelectric point [12] of the enzyme. All three parameters can be used as an index for the mean age of the CK M-chain in the blood. It is to be expected that the modifying protein also influences the physicochemical characteristics of the CK MB isozyme [2].

Our data show that there are measurable changes in the Michaelis-Menten constants due to changes in the temperature of the assay. The greatest effect is observed for $K_{\text {ia }}$ and hence, due to the log-linear variation of $K$ with respect to the reciprocal temperature, the apparent standard enthalpy changes for substrate binding here show their highest values. We therefore conclude that the greatest enthalpy change of up to $50 \mathrm{~kJ} / \mathrm{mol}$ takes place when the enzyme reacts with ADP as its first substrate. The subsequent reaction with creatine phosphate as the second substrate gives an additional enthalpy changes of about $15 \mathrm{~kJ} / \mathrm{mol}$. The enthalpy changes for the alternative pathway with creatine phosphate as the first substrate are intermediate. Theoretically the sum of Delta $\mathrm{Hs}\left(K_{\mathrm{ia}}\right)$ and Delta Hs $\left(K_{\mathrm{b}}\right)$ should equal the sum of Delta $\mathrm{Hs}\left(K_{\mathrm{a}}\right)$ and Delta $\mathrm{Hs}\left(K_{\mathrm{ib}}\right)$. As can be deduced from the values given in the Tables II and III for these constants this actually holds true for each of the three CK MM multiple forms (for instance in cases of $\mathrm{CK} \mathrm{MM}_{3}: K_{\mathrm{ia}}=42$, $K_{\mathrm{b}}=17, K_{\mathrm{ib}}=22$ and $K_{\mathrm{a}}=36 ; 42+17=22+36$ ). This provides a validation of our measuring results. Due to differences in kinetic properties among $C K$ isozymes and among the three CK MM multiple forms, it is advised not to compare catalytic $\mathrm{CK}$ activities measured at different temperatures. There are two reasons for this. 1. The main effect on the temperature coefficient for the catalytic activity is related to the apparent activation energy of the multiple forms that occur in varying and unknown amounts in the samples. 2. A smaller effect is due to the variation of the Michaelis-Menten constants of the multiple forms with temperature, so that the enzyme saturation with substrate is also temperature dependent.

The determinations cannot be performed under saturated substrate conditions due to substrate inhibition. Catalytic activity is determined under suboptimal conditions for this reason (Table IV). Table IV shows that $\mathrm{CK} \mathrm{MM}_{1}$ reacts at $83.3 \%$ of $V_{\mathrm{r}}$ at $25^{\circ} \mathrm{C}$ and at $76.9 \%$ of $V_{\mathrm{r}}$ at $37^{\circ} \mathrm{C}$. The differences for $\mathrm{CK} \mathrm{MM}_{3}$ are even greater. In serum samples the contribution of the various $\mathrm{MM}$ forms to the overall activity is unknown. Therefore, no exact factor can be given for the calculation of the activity at another temperature. For CK MM these tempcrature conversion factors $\left(25-37^{\circ} \mathrm{C}\right)$ vary from $2.17\left(\mathrm{CK} \mathrm{MM}_{3}\right)$ to $2.84\left(\mathrm{CK} \mathrm{MM}_{1}\right)$. This illustrates to what extent such a factor is subject to errors due to enzyme ageing. Different sample compositions of the multiple CK forms influence the catalytic activity in the same way isozymes do. This observation is of importance both for recommendations for 
the measurement of enzyme activity and for quality control in clinical chemistry. There are still open questions concerning the specific activity of the multiple forms. Activation energy is considered to be a quantitative measure of the 'energy barrier' between substrate and product. The increase in activation energy in the order $\mathbf{M M}_{3}$, $\mathrm{MM}_{2}, \mathrm{MM}_{1}$ indicates that $\mathrm{MM}_{3}$, the original tissue form of the enzyme, possesses the highest catalytic efficiency among the multiple forms. The Michaelis-Menten constants, on the other hand, increase in the order $\mathrm{MM}_{1}, \mathrm{MM}_{2}, \mathrm{MM}_{3}$, indicating that the original tissue form $\mathrm{CK} \mathrm{MM}_{3}$ has the lowest affinity for its substrates. The higher activation energy in case of $\mathrm{CK} \mathrm{MM}_{1}$ seems to be compensated by a higher substrate affinity. Yet the extent of compensation remains unknown until one is able to measure the concentration of the enzyme multiple forms, for instance by making use of an immunoassay specific for the various MM forms.

For the calculation of the extent of a myocardial infarction it is important that all three forms have similar specific activities. Discrepancies in the size of the infarct determined enzymatically and angiographically [26] might be explained by variations in specific activity. Proportionality between catalytic activity and the amount of enzyme present plays a central role in the use of catalytic activity in clinical diagnoses. This proportionality is threatened by the existence of various isozymes but also by the existence of multiple forms with different specific activities and different activation energies.

\section{References}

1 Wevers RA, Olthuis HP, Van Niel JCC, Van Wilgenburg MGM, Soons JBJ. A study on the dimeric structure of creatine kinase (EC 2.7.3.2). Clin Chim Acta 1977; 75: 377-385.

2 Wevers RA, Delsing M, Klein Gebbink JAG, Soons JBJ. Post synthetic changes in creatine kinase isozymes (EC 2.7.3.2). Clin Chim Acta 1978; 86: 323-327.

3 Falter H, Michelutti L, Mazzuchin A, Whiston W. Studies on the subbanding of creatine kinase MM and the 'CK conversion factor'. Clin Biochem 1981; 14: 3-7.

4 Chapelle J, Heusghem C. Further heterogeneity demonstrated for creatine kinase MM. Clin Chem 1980; 26: $457-462$.

5 Yasmineh WG, Yamada MK, Cohn JN. Postsynthetic variants of creatine kinase MM. J Lab Clin Med 1981; 98: 109-118.

6 Hagelauer U, Faust U. Analysensystem zur Bestimmung der Aktivierungsenergie von enzymatischen Reaktionen. Biomed Tech 1981; 26: 135-138.

7 Wevers RA, Boegheim JPJ, Hommes OR, Van Landeghem AAJ, Mul-Steinbusch MWFJ, Van der Stappen JWJ, Soons JBJ. A study of post-synthetic modifications in alfa-alfa enolase (EC 4.2.1.11) brought about by a human serum protein. Clin Chim Acta 1984; 139: 127-135.

8 Edwards RJ, Watts DC. Human 'creatine kinase conversion factor' identified as a carboxypeptidase. Biochem J 1984; 221: 465-470.

9 Perryman MB, Knell JD, Roberts R. Carboxypeptidase-catalyzed hydrolysis of C-terminal lysine: mechanism for in vivo production of multiple forms of creatine kinase in plasma. Clin Chem 1984; 30 : $662-664$

10 Hagelauer $U$, Faust $U$. The catalytic activity and activation energy of creatine kinase isoenzymes. $J$ Clin Chem Clin Biochem 1982: 633-638.

11 Nealon DA, Henderson AR. Separation of creatine kinase isoenzymes in serum by ion exchange column chromatography. Clin Chem 1975; 21: 392-397.

12 Wevers RA, Wolters RJ, Soons JBJ. Isoelectric focusing and hybridization experiments on creatine kinase. Clin Chim Acta 1977; 78: 271-276. 
13 Florkin M, Stot7. F, eds. Comprehensive hinchemistry, vol. 12. Amsterdam: Flsevier, 1964

14 Fromm HJ. Initial rate enzyme kinetics. Berlin, Heidelberg, New York: Springer Verlag, 1975.

15 Wilkinson GN. Statistical estimations in enzyme kinetics. Biochem J 1961; 80: 324-332.

16 Eisenthal R, Cornish-Bowden A. The direct linear plot. Biochem J 1974; 139: 715-720.

17 Porter W, Trager W. Improved non-parametric statistical methods for the estimation of Michaelis Menten kinetic parameters by the direct linear plot. Biochem J 1977: 161: 293-302.

18 Helger R. Creatine kinase isoenzymes, Vol. 34. Lang H, ed. Berlin, Heidelberg, New York: Springer Verlag, 1981.

19 Morrison JF. Approaches to kinetic studies on metal-activated enzymes. Methods Enzymol 1979; 63: 257-294.

20 Morrison JF, James E. The mechanism of the reaction catalysed by adenosin triphosphate creatine phosphotransferase. Biochem J 1965: 37-52.

21 Hagelauer U, Faust U, Trendelenburg C, Kruse-Jarres J. Rudolph T, Both A. Determination of activation energy of creatine kinase isocnzymes. J Clin Chem Clin Biochem 1983; 21: 874-876.

22 Stein W, Bohner J, Steinhart R, Eggstein M. Macro creatine kinase: determination and differentiation of two types by their activation energies. Clin Chem 1982: 28: 19-24.

23 McQueen MJ. True Arrhenius relationships of human lactate dehydrogenase. J Clin Chem Clin Biochem 1975; 13: 17-19.

24 Paule MR. The effect of temperature on the kinetics of adenosine diphosphoglucose pyrophosphorylase from Rhodospirillum rubrum. Biochemistry 1971; 10: 4509-4517.

25 Schmidt E, Schmidt FW. Ueber Aenderungen der Substrat Affinitaet von Malat-Dehydrogenase. Klin Wochenschr 1960; 38: 810-811.

26 Habel F. CK concentration - an indicator of infarct size? Z Kardiol 1980; 69: 11-17. 